\title{
DETERMINANT FACTORS THAT INFLUENCE THE ORIGINAL INCOME OF THE VILLAGE
}

\section{Farida Rika Arini, Icih, Trisandi Eka Putri}

Sekolah Tinggi Ilmu Ekonomi Sutaatmadja Subang

Email: icih@stiesa.ac.id

\begin{tabular}{|c|c|}
\hline INFO ARTIKEL & ABSTRACT \\
\hline $\begin{array}{l}\text { Histori Artikel : } \\
\text { Tgl. Masuk : 22-02-2021 } \\
\text { Tgl. Diterima : 25-03-2021 } \\
\text { Tersedia Online : 31-03-2021 } \\
\text { Keywords: } \\
\text { Village financial management, Village } \\
\text { building index, Village consultative } \\
\text { bodies , original income of the village. }\end{array}$ & $\begin{array}{l}\text { This study aims to determine the factors that influence the original } \\
\text { income of the village. The objects in this study are villages in the } \\
\text { Subang Districts area. This research is a quantitative study using } \\
\text { secondary data types. The sample selection technique uses } \\
\text { purposive sampling to produce } 103 \text { villages. The results showed } \\
\text { that: (1) Village financial management partially has a significant } \\
\text { positive effect on village original income, (2) Village building index } \\
\text { partially has no effect on the original income of the village, (3) } \\
\text { education level of the aparatur of the village government partially } \\
\text { did not have effect on village original income, (4) Village } \\
\text { consultative bodies partially do not affect the village's original } \\
\text { income, (5) village financial management, village building index, } \\
\text { education level of the aparatur of the village government and } \\
\text { village consultative bodies simultaneously have a significant } \\
\text { effect on village original income. }\end{array}$ \\
\hline
\end{tabular}

\section{PENDAHULUAN}

Kebijakan pemerintah pusat mengenai pemerintah daerah yang tercantum dalam Undang- Undang Nomor 23 Tahun 2014 tentang Pemerintahan Daerah menjelaskan bahwa sebagai daerah otonom, provinsi dan kabupaten/kota memiliki hak, wewenang, dan kewajiban untuk mengatur dan mengurus sendiri urusan pemerintahan dan kepentingan masyarakat setempat sesuai dengan peraturan perundang-undangan, sehingga sumber keuangan diberikan kepada pemerintah daerah untuk dapat membiayai penyelenggaraan pemerintahan dan pembangunan di daerahnya masing-masing. Konsep pembangunan tersebut harus lebih diarahkan lagi pada pembangunan berbasis tingkatan terendah dalam suatu struktur pemerintahan yaitu Desa (Ma'ruf, dkk, 2017). Pengakuan otonomi daerah pada tingkat desa diperkuat oleh 
Undang-Undang No.6 Tahun 2014 tentang Desa, Desa tidak hanya menjadi objek pembangunan melainkan menjadi ujung tombak pembangunan serta peningkatan kesejahteraan masyarakat. Berdasarkan hal tersebut, Presiden Jokowi merancang sembilan agenda prioritas yang disebut dengan Nawa Cita, khususnya cita ke-3, yaitu "Membangun Indonesia dari Pinggiran Dengan Memperkuat Daerah-Daerah dan Desa Dalam Kerangka NKRI" (Indrawati, 2017).

Pemerintah pusat setiap tahun telah menganggarkan dana desa yang cukup besar untuk diberikan kepada Desa. Hal ini terdapat dalam tujuan Rencana Pembangunan Jangka Menengah Nasioanl 2015- 2019, yaitu mengurangi jumlah desa tertinggal sebanyak 5.000 Desa dan meningkatkan jumlah desa mandiri sedikitnya 2.000 Desa. Salah satu indikator desa mandiri adalah besarnya pendapatan asli desa yang terus meningkat. Pendapatan asli desa atau yang disingkat PADesa merupakan pendapatan yang diperoleh dan digali dari potensi pendapatan yang ada di desa untuk menunjang penyelenggaraan pemerintahan dalam rangka pelaksanaan otonomi desa (Permendagri No. 113 Tahun 2014). Jika PADesa bisa ditingkatkan maka desa akan mendapatkan dana pengelolaan dan pembiayaan pembangunan untuk desa tersebut, sehingga akan terwujud kemandirian desa dalam memenuhi kebutuhan pembangunan fasilitas-fasilitas umum di desa (Balandatu, 2016). Desa mandiri adalah ketika suatu Desa dapat memenuhi kebutuhannya sendiri dan tidak semata-mata bergantung pada bantuan pemerintah (Basirrudin, 2012 dalam Atmadja, et al 2018). Kesadaran masyarakat desa untuk meningkatkan PADes masih harus ditingkatkan. Ketergantungan dana dari pusat dan pemerintah daerah masih sangat kuat. Desa belum dapat mengoptimalkan sumber pendapatan desa berdasarkan kekayaan dan potensi desa setempat (Supriadi, et al : 2016).

Adapun salah satu faktor yang dapat meningkatkan PADesa adalah pengelolaan keuangan Desa (Permemdagri No. 113 Tahun 2014). Pengelolaan pendapatan asli desa yang seharusnya sesuai dengan peraturan yang berlaku saat ini, dalam pelaksanaanya masih banyak penyimpangan (Astuti, 2015). Keuangan desa berhubungan dengan hak dan kewajiban desa. Pengelolaan keuangan desa merupakan keseluruhan aktivitas yang meliputi perencanaan, pelaksanaan, penatausahaan, pelaporan, dan pertanggungjawaban keuangan desa (Permendagri No. 113 Tahun 2014). Setiap aktivitas-aktivitas tersebut harus memperhatikan peningkatan pendapatan asli desa, salah satunya adanya anggaran 
pembentukan BUMDes. Jika pengelolaan keuangan desa berjalan dengan baik maka pada waktunya akan meningkatka PADes menuju desa mandiri.

Faktor lain yang diduga mempengaruhi PADes adalah tipologi desa yang diwujudkan dalam Indeks Desa Membangun (IDM). Seperti telah disebutkan di atas bahwa pembangunan desa saat ini masih bergantung kepada pendapatan transfer, salah satunya dana desa. Penggunaan dana desa harus mempertimbangkan tipologi desa yang terdiri atas desa tertinggal, berkembang, maju dan mandiri (PermendesPDTT No. 2 Tahun 2016). Tipologi desa merupakan dasar penentuan prioritas penggunaan dana desa yang sesuai dengan kebutuhan desa tersebut. Kebutuhan pembangunan masing-masing jenis desa tidak akan sama tetapi harus sesuai dengan kondisi tipologi desa tersebut. Jika desa memahami tipologi desanya dan menggunakan dana desa sesuai dengan kebutuhan desanya (sesuai tipologi desa) maka dana desa akan lebih efektif dan pada waktunya akan meningkatkan PADes.

Faktor lain yang mempengaruhi PADes adalah tingkat Pendidikan aparatur pemerintah desa. Pelaksanaan pembangunan dan pemberdayaan masyarakat dikoordinir oleh aparatur pemerintah desa. Oleh karena itu, aparatur pemerintah desa memegang peranan yang sangat penting dalam pembangunan desa. Aparatur pemerintah desa harus memiliki tingkat Pendidikan minimal yang harus dipenuhi - Kualitas sumber daya manusia khususnya aparatur pemerintah desa yang baik dapat dikembangkan melalui tingkat pendidikan (Rizki, 2014). Pemerintah Desa harus memiliki tingkat pendidikan seperti yang disyaratkan (Pasal 33d dan 50a dalam UU RI No. 6 Tahun 2014), yakni kepala desa berpendidikan minimal sekolah menengah pertama untuk sedangkan untuk perangkat desa berpendidikan paling rendah sekolah menengah umum atau sederajat. Jika tingkat Pendidikan aparatur pemerintah desa sesuai dengan ketentuan maka pengelolaan keuangan desa dapat berjalan efektif, sehingga pada akhirnya dapat meningkatkan PADes.

Faktor lain yang diduga mempengaruhi PADes adalah badan permusyawaratan desa. Pembangunan desa dilaksanakan oleh kepala desa sebagai lembaga eksekutif dan dipertanggungjawabkan kepada BPD sebaai lembaga legislatif di desa. Badan Permusyawaratan Desa adalah lembaga yang melaksanakan fungsi pemerintahan yang anggotanya merupakan wakil dari penduduk Desa yang ditetapkan secara demokratis dengan tetap memperhatikan keterwakilan wilayah (Permendagri No. 110 Tahun 2016). Setiap proses dalam pengelolaan keuangan desa selalu 
melibabatkan BPD sebagai lembaga legislative, termasuk dalam hal pembentukan sumber-sumber PADes. Jika BPD berperan aktif menjelankan fungsinya maka PADes dapat tercapai. Hal tersebut didukung oleh penelitian Widayanto, A (2016) yang menunjukkan bahwa BPD berperan dalam pengoptimalisasian peningkatan pendapatan asli desa.

Penelitian ini mengembangkan penelitian Widayanto, A (2016) dengan menambahkan beberapa variabel independen seperti pengelolaan keuangan desa, Indeks Desa Membangun, tingkat pendidikan aparatur pemerintah desa dan badan permusyawaratan desa. Penelitian dilakukan terhadap desa-desa di Kabupaten Subang.

\section{KERANGKA TEORITIS DAN PENGEMBANGAN HIPOTESIS}

Penelitian ini didasari oleh Stewardship theory (Donaldson \& Davis 1989a,1991b dalam Davis et al ,1997). Stewardship theory memandang aparatur pemerintah desa sebagai pihak yang dapat dipercaya untuk bertindak dengan sebaik-baiknya bagi kepentingan publik pada umumnya dan stakeholder pada khususnya (Queena, 2012). Aparatur pemerintah desa yang bertindak sebagai steward, memiliki tanggung jawab terhadap publik dan pemerintah di tingkat kabupaten/kota, provinsi maupun pusat, yang mana bertindak sebagai principal.

\section{Pengaruh Pengelolaan Keuangan Desa terhadap Pendapatan Asli Desa}

Keuangan Desa adalah segala hak dan kewajiban Desa yang dapat dinilai dengan uang serta segala sesuatu berupa uang dan barang yang berhubungan dengan pelaksanaan hak dan kewaijiban Desa (Pasal 1 ayat 10 UU No. 6 Tahun 2014). Hak dan Kewajiban Desa tersebut dapat menimbulkan pendapatan, belanja, pembiayaan, dan pengelolaan keuangan Desa. Disebutkan dalam pasal 67 ayat 1c bahwa Desa memiliki hak untuk mendapatkan sumber pendapatan yang termasuk didalamya pendapatan asli desa, disamping memiliki hak, Desa juga memiliki kewajiban yang salah satunya adalah pengelolaan keuangan Desa. Pengelolaan Keuangan Desa dalam satu tahun siklus anggaran merupakan segala aktivitas yang berkaitan dengan perencanaan, pelaksanaan, penatausahaan, pelaporan dan pertanggungjawaban.

Pengelolaan keuangan desa dilakukan setiap tahun secara terus menerus. Jumlah keuangan desa 
mengalami peningkatan sejak adanya dana desa. Pengelolaan keuangan tahun sekarang dipengaruhi oleh pengelolaan keuangan tahun sebelumnya. Pengelolaan keuangan tahun sekarang akan mempengaruhi pengelolaan keuangan tahun selanjutnya. Adanya desa mandiri, yang dibuktikan dengan peningkatan PADes tidak akan tercapai hanya dalam satu kali pengelolaan keuangan saja.Jika sejak awal pengelolaan keuangan sudah berjalan efektif maka peningkatan PADes akan dicapai dalam waktu yang lebih cepat. Sebaliknya jika pengelolaan keuangan desa sejak awal tidak efektif maka peningkatan PADes memerlukan waktu yang lebih lama. Pengelolaan keuangan desa diproksikan dengan total belanja desa. Anggaran belanja ditetapkan maksimal sama dengan anggaran Pendapatan. Jika anggaran belanja tahun-tahun sebelumnya dapat direalisasikan $\quad 100 \%$ maka peningkatan PADes akan bisa dicapai dalam waktu yang lebih cepat. Realisasi belanja desa 100\% tidak akan tercapai jika perencanaan, pelaksanaan, penatausahaan, pelaporan dan pertanggungjawaban keuangan desa tidak berjalan dengan baik. Berdasarkan uraian di atas maka dapat ditarik hipotesis (H1) bahwa pengelolaan keuangan desa berpengaruh positif terhadap PADes.

\section{Pengaruh Indeks Desa Membangun terhadap Pendapatan Asli Desa \\ Tujuan \\ Rencana}

Pembangunan Jangka Menengah Nasional (RPJMN) 2015-2019 yakni mengentaskan 2.000 Desa Tertinggal dan meningkatkan sedikitnya 5.000 Desa Mandiri. Desa Tertinggal merupakan kondisi desa yang ingin dikurangi jumlahnya sedangka Desa Mandiri merupakan kondisi desa yang ingin dicapai atau ditambah jumlahnya. Setiap desa mempunyai kondisi dan masalah yang berbeda, sehingga diperlukan adanya status indeks desa menurut keadaan desa masing-masing. Indeks ini dikenal dengan nama Indeks Desa Membangun (IDM). Menurut PermendesPDTT Republik Indonesia Nomor 2 Tahun 2016, Indeks Desa Membangun adalah Indeks Komposit yang dibentuk dari Indeks Ketahanan Sosial, Indeks Ketahanan Ekonomi dan Indeks Ketahanan Ekologi Desa. IDM terdiri dari Desa sangat tertinggal, Desa tertinggal, Desa berkembang, Desa 
maju dan Desa Mandiri. Pencapaian tujuan sebagai Desa Mandiri . Tujuan setiap pembangunan desa adalah menjadi desa mandiri. Pencapaian tujuan tersebut tergantung dari kondisi desa pada saat ini. Desa harus melakukan self assessment kondisi saat ini agar bisa menjadi Desa Mandiri. Desa Sangat Tertinggal membutuhkan waktu yang lebih lama untuk mencapai desa mandiri daripada Desa Tertinggal dan seterusnya. Apa yang dibutuhkan oleh Desa Sangat Tertinggal untuk mencapai Desa Mandiri pasti berbeda dengan apa yang dibutuhkan oleh Desa Tertinggal untuk mencapai Desa Mandiri dan seterusnya. Kesadaran akan IDM desa masing-masing akan menimbulkan kesadaran resikoresiko apa yang akan dihadapi dalam mencapai Desa Mandiri. Desa harus bisa mengurangi resiko-resiko yang akan dihadapi untuk mencapai Desa Mandiri. IDM desa saat ini akan mempengaruhi pencapaian tujuan menjadi Desa Mandiri. Desa Mandiri diproksikan dengan PADes yang tinggi .Berdasarkan uraian tersebut dapat ditarik hipotesis (H2) bahwa Indeks Desa Membangun (IDM) berpengaruh positif terhadap PADes.
Pengaruh Tingkat Pendidikan Aparatur Pemerintah Desa terhadap Pendapatan Asli Desa

Suatu organisasi dalam mencapai tujuannya membutuhkan sumber daya manusia. Tumbuh kembangnya suatu organisasi bergantung pada pada sumber daya manusia yang memiliki kualitas tinggi. Oleh karena itu, sumber daya manusia harus diperhatikan dengan baik agar terjadi peningkatan efisiensi, efektivitas, dan produktivitas kerja yang tercermin pada kinerja semua pihak, baik yang masuk kategori tugas pokok maupun tugas penunjang serta pimpinan. Kualitas sumber daya manusia yang baik dapat dikembangkan melalui peningkatan pendidikan (Rizki, 2014). Menurut Murina, S dan Rahmawaty (2017) Pendidikan merupakan proses pembelajaran untuk menghimpun dan meningkatkan pengetahuan. Pendidikan diperoleh melalui pembelajaran secara terstruktur dan dalam waktu yang relatif lama. Pendidikan dapat meningkatkan kualitas seseorang. Orang yang berpendidikan akan lebih rasional dalam berpikir dan bertindak, serta memahami tugas dan tanggung jawabnya dengan baik,tidak terkecuali untuk aparatur pemerintah Desa. 
Aparatur pemerintah desa dalam melakukan pengelolaan keuangan Desa yang mengacu pada IDM sehingga tujuan menjadi Desa Mandiri dapat tercapai memerlukan adanya suatu tingkat kompetensi Pendidikan. Hal ini sesuai dengan Pasal 33 point $d$ dalam UU No. 6 Tahun 2014 yang mengatakan bahwa Kepala Desa berpendidikan paling rendah tamat sekolah pertama atau sederajat sedangkan untuk perangkat desa berpendidikan paling rendah sekolah menengah umum atau yang sederajat, hal tersebut tercantum dalam pasal 50 point a dalam UU No. 6 Tahun 2014.

Aparatur pemerintah desa yang mempunyai tingkat Pendidikan yang sesuai dengan peraturan akan mempermudah pencapaian Desa Mandiri yang diproksikan dengan PADes. Berdasarkan hal tersebut maka dapat ditarik hipotesis $(\mathrm{H} 3)$ bahwa tingkat Pendidikan aparatur pemerintah desa berpengaruh positif terhadap PADes.

\section{Pengaruh Badan Permusyawaratan Desa terhadap Pendapatan Asli Desa}

Menurut Permendagri No. 110 Tahun 2016 Badan Permusyawaratan Desa yang selanjutnya disingkat BPD atau disebut dengan nama lain adalah lembaga yang melaksanakan fungsi pemerintahan yang anggotanya merupakan wakil dari penduduk Desa berdasarkan keterwakilan wilayah dan ditetapkan seacara demokratis. BPD sebagai lembaga legislasi mengawasi aparatur pemerintah desa dalam melaksanakan tugasnya. Aparatur pemerintah desa, khususnya kepada desa, harus menyampaikan pertanggungjawaban kepada BPD. BPD memberikan arahan-arahan agar tujuan pembangunan desa dapat tercapai yaitu menjadi Desa Mandiri yang diproksikan dengan PADes.Aparatur pemerintah desa pada saat melakukan perencanaan keuangan desa harus mendapat persetujuan BPD, contonya pada saat penyusunan APBDesa. Begitu pula pada tahap pengelolaan keuangan desa yang lainnya sampai dengan pertanggungjawaban kepada BPD. Jika BPD dapat menjalankan perannya dengan baik maka tujuan menjadi Desa Mandiri yang diproksikan dengan PADes akan cepat terwujud. Seperti yang dikemukakan oleh Widayanto, A (2016) dalam penelitiannya menunjukkan bahwa peran BPD dalam pengoptimalisasian peningkatan pendapatan asli desa serta peran dalam rangka pengelolaan 
pemanfaatan pendapatan asli desa untuk kesejahteraan Desa dinilai sudah memuaskan. Berdasarkan uraian tersebut maka dapat ditarik suatu hipotesis $(\mathrm{H} 4)$ bahwa BPD berpengaruh positif terhadap PADes.

Berdasarkan uraian variabelvariabel independent di atas, maka dapat ditarik hipotesis (H5) bahwa Pengelolaan Keuangan Desa, Indeks Desa Membangun, Tingkat Pendidikan Aparatur Pemerintah Desa dan Badan Permusyawaratan Desa secara simultan berpengaruh terhadap Pendapatan Asli Desa.

\section{METODOLOGI PENELITIAN}

Jenis, Sumber dan Teknik Pengumpulan Data

Penelitian ini merupakan penelitian kuantitatif dengan menggunakan data sekunder dari Dinas Pemberdayaan Masyarakat dan Desa, Badan Keuangan dan Aset Daerah (BKAD), dan Kecamatan se-Kabupaten Subang serta studi kepustakaan yang didapat dari web, berita, jurnal, artikel, skripsi, tesis, buku-buku yang relevan dan sumber lainnya yang berkaitan dengan variabel-variabel yang diteliti.

\section{Definisi dan Pengukuran Variabel Penelitian}

Pada penelitian ini digunakan dua jenis variabel, yaitu variabel independen dan variabel dependen.
1. Variabel Dependen $(Y)$

Variabel dependen adalah pendapatan asli desa (Y). Variabel ini diukur dengan menggunakan logaritma natural total pendapatan asli desa pada ikhtisar laporan pertanggungjawaban realisasi pelaksanaan APBDesa tahun $\mathrm{t}$ (Manzon dan Plesko, 2002). Tahun t adalah tahun 2017. Pendapatan Asli Desa $=$ Ln (total PADesa tahun 2017)

2. Variabel Independen (X) Pengelolaan Keuangan Desa

Variabel ini diproksikan dengan menggunakan total belanja yang diukur dengan menggunakan logaritma natural total belanja tahun sebelumnya (2016) pada ikhtisar laporan pertanggungjawaban realisasi pelaksanaan APBDesa tahun t (Manzon dan Plesko, 2002). Pengelolaan Keuangan Desa=Ln (total Belanja tahun $\mathrm{t}-1)$

a. Indeks Desa Membangun Variabel ini menggunakan data hasil olahan PermendesPDTT kemudian diberi nilai 1 s/d 5, dimulai Desa sangat tertinggal (nilai 1), Desa tertinggal (nilai 2), Desa berkembang (nilai 3), Desa maju (nilai 4) dan Desa Mandiri (nilai 5).

b. Tingkat Pendidikan Aparatur Pemerintah Desa

Variabel ini di ukur dengan menggunakan memberikan poin, dimana apabila sesuai dengan peraturan (UU No. 6 Tahun 2014) 
maka diberi nilai 1 dan 0 tidak sesuai yang kemudian diolah kedalam bentuk rasio.

c. Badan Permusyawaratan Desa Variabel ini diukur dengan memberikan poin dimana apabila sesuai peraturan (Permendagri No. 110 Tahun 2016) diberi nilai 1, tidak sesuai diberi nilai 0 kemudian diolah kedalam bentuk rasio.

\section{HASIL DAN PEMBAHASAN}

Pengolahan data menggunakan SPSS versi 22 dengan hasil dapat dilihat pada tabel sebagai berikut:

Dari hasil analisis dengan program SPSS versi 22 tersebut, maka dapat diketahui persamaan regresi yang terbentuk. Adapun persamaan regersi linier berganda adalah sebagai berikut:

Tabel 2

Hasil Uji Signifikan Parameter Individual

\begin{tabular}{|c|c|c|c|}
\hline \multicolumn{2}{|c|}{ Model } & \multirow{2}{*}{$\begin{array}{c}\mathbf{T} \\
-2.850\end{array}$} & \multirow{2}{*}{$\begin{array}{l}\text { Sig. } \\
.005\end{array}$} \\
\hline \multirow{5}{*}{1} & $\begin{array}{l}\text { (Constant } \\
\text { ) }\end{array}$ & & \\
\hline & LN_X1 & 3.936 & .000 \\
\hline & $x 2$ & -.243 & .809 \\
\hline & X3 & .653 & .515 \\
\hline & $X 4$ & 1.957 & .053 \\
\hline
\end{tabular}

Sumber: Hasil Pengolahan SPSS, 2019

$$
\begin{gathered}
\mathrm{Y}=-46,476+2,975 \mathrm{X} 1+(-0,057 \mathrm{X} 2) \\
+0,699 \mathrm{X} 3)+1,103 \mathrm{X} 4
\end{gathered}
$$

Hasil statistic t untuk penelitian ini dapat dilihat pada tabel berikut:

Variabel X1 (Pengelolaan Keuangan Desa) memperoleh thitung (3.936) > ttabel $(1,66039)$ dengan sig. 0,000 $<0,05$, maka $\mathrm{H} 1$ diterima yang berarti Variabel Pengelolaan Keuangan Desa berpengaruh positif signifikan terhadap PADesa. Variabel $\mathrm{X} 1$ yang diproksikan dengan total belanja tahun 2016 sebesar Rp179.756.481.821. Total belanja tersebut dibagi ke dalam 5 jenis Bidang Belanja, yaitu Bidang Penyelenggaraan Pemerintah Desa sebesar Rp58.399.762.780 atau 34\%, Bidang Pelaksanaan Pembangunan Desa

Tabel 1

\begin{tabular}{|c|c|c|c|}
\hline & \multirow{2}{*}{ Model } & \multicolumn{2}{|c|}{ Unstandardized Coefficients } \\
\hline & & B & Std. Error \\
\hline & (Constant) & -46.476 & 16.310 \\
\hline 1 & LN_X1 & 2.975 & .756 \\
\hline & $\mathrm{X} 2$ & -.057 & 0.236 \\
\hline & X3 & .699 & 1.069 \\
\hline & $X 4$ & 1.103 & .564 \\
\hline
\end{tabular}

Hasil Uji Regresi

Sumber: Hasil Pengolahan SPSS, 2019

sebesar Rp95.968.762.926 atau 56\%, Bidang Pembinaan Kemasyarakatan sebesar Rp. 6.788.448.355 atau 4\%, Bidang Pemberdayaan Masyarakat sebesar Rp8.196.204.516 atau 5\% dan Bidang Tak Terduga sebesar 
Rp854.783.730 atau 1\%. Pendapatan asli desa yang diperoleh sebesar Rp14.962.302.602. Walaupun pencapaian PADes masih rendah jika dibandingkan dengan total belanja yang dikeluarkan tetapi pengelolaan keuangan telah menunjukkan langkah awal pembentukan PADes. Sebagian besar belanja (56\%) digunakan untuk pembangunan infrastruktur. Infrastruktur merupakan hal yang penting dalam pencapaian PADes, contohnya jalan raya. Sebagus apapun sumber pendapatan asli desa tanpa adanya jalan yang menghubungkan antara pihak pihak yang berkepentingan maka sumber tersebut tidak akan menghasilkan pendapatan bagi desa. Pengelolaan keuangan desa di Kabupaten Subang sudah mengarah kepada pencapaian peningkatan PADes, yaitu melalui pembangunan infrastruktur desa.

Variabel X2 (Indeks Desa Membangun/IDM), diperoleh thitung ($0.243)<$ ttabel $(1,66039)$ dengan sig. 0,809 $>0,05$, maka $\mathrm{H} 2$ ditolak artinya Variabel Indeks Desa Membangun tidak berpengaruh positif secara terhadap PADesa. IDM desa di Kabupaten Subang terdiri atas Desa Tertinggal 20\%, Desa Berkembang 69\% dan Desa Maju 11\%. Berdasarkan wawancara dengan aparatur pemerintah desa, sebagian besar belum mengetahui IDM masing-masing desanya, sehingga belum menggunakan IDM desa untuk pembangunan desa menuju Desa Mandiri. Pembangunan desa belum memperhitungkan IDM desa pada saat ini. Sebagian besar IDM di Kabupaten Subang sebagai Desa Berkembang. Desa Berkembang bukan desa yang mengalami kerentanan karena masalah bencana alam, goncangan ekonomi, dan konflik sosial sehingga tidak berkemampuan mengelola potensi sumber daya sosial, ekonomi, dan ekologi, serta mengalami kemiskinan dalam berbagai bentuknya Desa Berkembang, atau bisa disebut sebagai Desa Madya adalah Desa potensial menjadi Desa Maju, yang memiliki potensi sumber daya sosial, ekonomi, dan ekologi tetapi belum mengelolanya secara optimal untuk peningkatan kesejahteraan masyarakat Desa, kualitas hidup manusia dan menanggulangi kemiskinan. Desa Berkembang tidak memiliki kerentanan dalam bidang ekonomi, social dan ekologi. Desa Berkembang tidak mengalami kemiskinan dalam berbagai bentuknya. Desa Berkembang tidak mengalami tekanan kemiskinan masyarakatnya. Berdasarkan hal tersebut maka semangat Desa Berkembang untuk meningkatkan PADes masih kurang karena merasa sudah berkecukupan walaupun belum maju dan mandiri, sehingga Indeks Desa Membangun tidak berpengaruh positif terhadap PADes.

Variabel X3 (Tingkat Pendidikan Aparatur Pemerintah Desa) memperoleh thitung $(0,653)<$ ttabel $(1,66039)$ dengan sig. 0,515 >0,05, maka H3 ditolak artinya Variabel Tingkat 
Pendidikan Aparatur Pemerintah Desa tidak berpengaruh positif terhadap PADesa.

Total aparatur pemerintah desa sebanyak 608 orang (103 desa), yang memiliki tingkat pendidikan SD sebanyak 6 orang, SMP sebanyak 68 orang, SMA sebanyak 430 orang, DIPL (Diploma) sebanyak 17 orang, S1 sebanyak 85 orang dan S2 sebanyak 2 orang. Sehingga dari data tersebut dapat disimpulkan bahwa aparatur pemerintah desa yang memiliki tingkat pendidikan sesuai ketentuan yang berlaku sebanyak 546 orang atau $90 \%$ sedangkan sisanya sebanyak 62 orang atau $10 \%$ memiliki tingkat pendidikan yang tidak sesuai. Sehingga pendidikan aparatur pemerintah desa yang sesuai dengan peraturan adalah sebanyak 65 Desa atau 63\%. Walaupun sebagian besar Pendidikan aparatur pemerintah desa sesuai dengan ketentuan tetapi tidak mempengaruhi PADes. Aparatur pemerintah desa sebagian besar berpendidikan SMA. Kurikulum SMA belum mengarah kepada pembentukan dan pengelolaan BUMDes sebagai sumber utama PADes, sehingga desa yang memiliki BUMDes baru mencapai 41\%. Berdasarkan hal tersebut maka tingkat Pendidikan aparatur pemerintah desa tidak berpengaruh positif terhadap PADes.

$$
\text { Variabel }
$$$$
\mathrm{X} 4
$$

(Badan

Permusyawaratan Desa/BPD) memperoleh thitung (1.957) > ttabel $(1,66039)$ dengan sig. 0,053 > 0,05, maka H4 ditolak artinya Variabel Badan
Permusyawaratan Desa tidak berpengaruh positif terhadap PADesa. Indikatorindikator BPD terdiri dari indicator tingkat Pendidikan, jumlah anggota, perwakilan perempuan dan perwakilan wilayah. Indikator tingkat pendidikan, dari total anggota sebanyak 918 orang, yang memiliki tingkat pendidikan SD sebanyak 22 orang, SMP sebanyak 113 orang, SMA sebanyak 526 orang, DIPL (Diploma) sebanyak 15 orang, S1 sebanyak 222 orang dan S2 sebanyak 20 orang. Sehingga dari data tersebut dapat disimpulkan bahwa anggota Badan Permusyawaratan Desa yang memiliki tingkat pendidikan sesuai ketentuan sebanyak 896 orang atau 98\% (92 Desa atau $89 \%$ ) sedangkan sisanya sebanyak 22 orang atau $2 \%$ memiliki tingkat pendidikan yang tidak sesuai ketentuan. Jumlah anggota Badan Permusyawaratan Desa yang sesuai dengan ketentuan adalah 50 Desa atau 49\%. Untuk Indikator keterwakilan perempuan, yang memenuhi ketentuan sebanyak 65 Desa atau 63\% dan untuk indikator Keterwakilan wilayah, semua Badan Permusyawartaan Desa seluruhnya telah memenuhi, yaitu sebanyak 103 Desa atau 100\%. Adapun Badan Permusyawaratan Desa yang memenuhi semua indikator adalah sebanyak 46 Desa atau 45\%. Jadi hanya $45 \%$ desa yang memiliki BPD sesuai dengan ketentuan yang berlaku,baik dari tingkat Pendidikan,jumlah anggota, keterwakilan perempuan dan wilayah. 
Berdasarkan hal tersebut maka BPD tidak berpengaruh positif terhadap PADes.

Pengujian secara simultan diperoleh Fhitung $(4,230)>$ Ftabel $(2,46)$ dan taraf signifikansinya $(0,003)<0,05, \mathrm{H} 5$ diterima artinya secara simultan Pengelolaan Keuangan Desa, Indeks Desa Membangun, Tingkat Pendidikan Aparatur Pemerintah Desa dan Badan Permusyawaratan Desa berpengaruh terhadap PADesa dengan nilai adjusted $R$ square $11,2 \%$ sedangkan sisanya sebesar $88,8 \%$ dijelaskan oleh variabel lain diluar variabel yang diteliti dalam penelitian ini.

\section{KESIMPULAN DAN SARAN}

Berdasarkan hasil pengujian dan pembahasan maka dapat disimpulkan:

1. Pengelolaan Keuangan Desa berpengaruh positif terhadap Pendapatan Asli Desa.

2. Indeks Desa Membangun tidak berpengaruh positif terhadap Pendapatan Asli Desa.

3. Tingkat Pendidikan Aparatur Pemerintah Desa tidak berpengaruh positif terhadap Pendapatan Asli Desa.

4. Badan Permusyawaratan Desa tidak berpengaruh positif terhadap Pendapatan Asli Desa.

5. Pengelolaan Keuangan Desa, Indeks Desa Membangun, Tingkat Pendidikan Aparatur Pemerintah Desa dan Badan Permusyawaratan Desa secara bersama-sama (simultan) berpengaruh terhadap Pendapatan Asli Desa.

\section{REFERENCES}

Atmadja, AT., Saputra, K. A.K., Koswara, M. K. (2018). The Influence Of Village
Conflict, Village Apparatus Ability, Village Facilitator Competency And Commitment Of Local Government OnThe Success Of Budget Management. Academy of Accounting and Financial Studies Journal, 1 (22). ISSN 1528-2635

Astuti, Indri. (2015). Pengelolaan Pendapatan Asli Desa Studi Kasus Di Desa Ngombakan Kecamatan Polokarto Kabupaten Sukoharjo Tahun 2014. Fakultas Keguruan Dan IImu Pendidikan. Universitas Muhammadiyah Surakarta. SKRPISI yang diterbitkan.

Balandatu, Evelin. (2016). Kebijakan Pemerintah Desa Dalam Meningkatkan Pendapatan Asli Desa Studi Di Desa Peling Kecamatan Siau Barat Kabupaten Kepulauan Siau Tagulandang Biaro. Jurnal Eksekutif, 1 (7). ISSN 2337-5736.

Bastian, Indra. (2015). Akuntansi Untuk Kecamatan dan Desa. Jakarta: Erlangga.

Davis, J.H., Schoorman, F.D., Donaldson, L. (1997). Toward A Stewardship Theory Of Management.

Academy of Management Review. 22
(1), 20-47. DOI:
10.5465/AMR.1997.970718025

Ghozali, Imam. (2016). Aplikasi Analisis Multivariate dengan Program IBM SPSS23. Edisi 8.

Semarang: Badan Penerbit Universitas Diponegoro.

Gujarati, D.N., Porter, D.C. (2015). Dasardasar Ekonometrika. Edisi 5. Jakarta: Salemba Empat. Hardiana, S.F., Idris, A., Dama, M. (2018). Upaya Peningkatan Pendapatan Asli Desa Dalam Pelaksanaan Pembangunan Desa di Desa Mansalong Kecamatan Lumbis Kabupaten Nunukan. e- 
Journal Ilmu Pemerintahan. 6 (2), 931 944. ISSN 2447-2458.

Indrawati, S.M. (2017). Buku Saku Dana Desa: Dana Desa Untuk Kesejahteraan Rakyat

Jannah,R., Handajani, L., dan Firmansyah, M. (2018). The Influence of Human Resources, Use of Information Technology and Public Participation to the Transparancy and Accountability of Village Financial Management Empirical Study In East Praya Subdistrict Of Central Lombok Regency. International Journal of Scientific Research and Management (IJSRM). 6 (5), 373- 385. ISSN (e): 2321-3418.

DOI:

10.18535/ijsrm/v6i5.em03

Ma'ruf, M.F., Kurniawan, B., dan Pangestu, R.PA.G. (2017). Desa Wisata: Sebuah Upaya Mengembangkan Potensi Desa Dan Meningkatkan Pendapatan Asli Desa Studi Pada Desa Wisata Bejiharjo Kecamatan Karangmojo Kabupaten Gunungkidul. Jurnal IImu Administrasi Negara, 7(2), 193-203.

Murina, S dan Rahmawaty. (2017). Pengaruh Tingkat Pendidikan, Kualitas Pelatihan, Dan Pengalaman Kerja Aparatur Desa Terhadap Pemahaman Laporan Keuangan Desa Studi Pada Kecamatan Banda Raya Kota Banda Aceh. Jurnal IImiah Mahasiswa Ekonomi Akuntansi. (2) 3, 111-120. EISSN 2581-1002.

Peraturan Menteri Dalam Negeri Republik Indonesia Nomor 83 Tahun 2015 Tentang Pengangkatan Dan Pemberhentian Perangkat Desa

Peraturan Menteri Dalam Negeri Republik Indonesia Nomor 113 Tahun 2014 Tentang Pengelolaan Keuangan Desa

Peraturan Menteri Dalam Negeri Republik Indonesia Nomor 110 Tahun 2016
Tentang Badan Permusyawaratan Desa

Peraturan Menteri Dalam Negeri Republik Indonesia Nomor 114 Tahun 2014 Tentang Pedoman Pembangunan Desa

Peraturan Menteri Desa, Pembangunan Daerah Tertinggal, Dan Transmigrasi Republik Indonesia Nomor 2 Tahun 2016 Tentang Indeks Desa Membangun

Peraturan Menteri Desa, Pembangunan Daerah Tertinggal, Dan Transmigrasi Republik Indonesia Nomor 4 Tahun 2017 Perubahan Atas Peraturan Menteri Desa, Pembangunan Daerah Tertinggal, dan Transmigrasi Nomor 22 Tahun 2016 Tentang Penetapan Prioritas Penggunaan Dana Desa Tahun 2017

Peraturan Pemerintah Republik Indonesia Nomor 8 Tahun 2016 Tentang Perubahan Kedua Atas Peraturan Pemerintah Nomor 60 Tahun 2014 Tentang Dana Desa Yang Bersumber Dari Anggaran Pendapatan dan Belanja Negara

Peraturan Menteri Desa, Pembangunan Daerah Tertinggal, Dan Transmigrasi Republik Indonesia Nomor 21 Tahun 2015 Tentang Penetapan Prioritas Penggunaan Dana Desa Tahun 2016

Peraturan Pemerintah Republik Indonesia Nomor 22 Tahun 2015 Tentang Perubahan Atas Peraturan Pemerintah No. 60 Tahun 2014 Tentang Dana Desa Yang Bersumber Dari Anggaran Pendapatan dan Belanja Negara.

Queena, P.R. (2012). Analisis FaktorFaktor Yang Mempengaruhi Kualitas Audit Aparat Inspektorat Kota/Kabupaten Di Jawa Tengah. Fakultas Ekonomika Dan Bisnis Universitas Diponegoro Semarang. SKRIPSI yang diterbitkan. 
Rizki, Muhammad. (2014). Hubungan Pendidikan Kepala Desa Dengan Kinerja Kepala Desa Di Desa Pepara Kecamatan Tana Paser. eJournal Administrasi Negara. 2 (4), 1890-1901.

Sekaran, Uma dan Bougie, Roger. (2017). Metode Penelitian Untuk Bisnis. Edisi 6. Jakarta Selatan: Salemba Empat.

Siregar, Syofian. (2015). Metode Penelitian Kuantitatif (Dilengkapi dengan perbandingan perhitungan manual dan SPSS). Edisi 1. Jakarta: Kencana Prenanda Media Group

Sugiyono. (2016). Metode Penelitian Kuantitatif, Kualitatif dan $R \& D$. Bandung: PT Alfabet.

Sujarweni, V. Wiratna. (2015). Akuntansi Desa Panduan Tata Kelola Keuangan Desa. Yogyakarta: Pustaka Baru Press.

Supriyadi., Praseyto, W., Irmadariyani, L. (2016). The Village's Financial Management Accountability Case Study On Klompangan Village Ajung Jember Regency. Proceedings International Conference on Business and Accounting Studies Faculty of Economics and Business University of Jember,. 614-638. ISBN 978-60260569-1-7.

Umar, Husein. (2014). Metode Penelitian untuk Skripsi dan Tesis Bisnis.Edisi Kedua. Jakarta: Rajawali Press
Umiyati, Indah dan Nurmalasari, Nunik. (2016). Statistik Penelitian Pengenalan Aplikasi SPSS dan EVIEWS. Subang: STIESA PRESS

Undang-Undang Republik Indonesia Nomor 6 Tahun 2014 Tentang Desa

Undang-Undang Republik Indonesia Nomor 23 Tahun 2014 Tentang Pemerintahan Daerah Widarnawati, B.W., Santoso, B., dan Suparman, L. (2018). Factors Affecting Of Village Financial Management and Its Implications For Stakeholders Trust Study On Villages In Central Lombok, Indonesia. International Journal of Economics, Commerce and Management. 6 (3), 534-548. ISSN 23480386.

Widayanto, Agus. (2011). Peranan Badan Permusyawaratan Desa (BPD) dalam Optimalisasi Peningkatan dan Pemanfaatan Pendapatan Asli Desa (PAD) Studi Eksplorasi di Desa Palem, Kecamatan Simo, Kabupaten Boyolali. Fakultas Keguruan dan IImu Pendidikan Universitas Muhammadiyah Surakarta. SKRIPSI yang diterbitkan.

Yuliansyah dan Rusmianto. (2016). Akuntansi Desa. Jakarta: Salemba Empat. 